\title{
A Study of the Semiotic Understanding of Land Art
}

\author{
Farzaneh Najafi $^{1} \&$ Merza Abbas ${ }^{1}$ \\ ${ }^{1}$ Centre for Instructional Technology \& Multimedia, Universiti Sains Malaysia, Penang, Malaysia \\ Correspondence: Farzaneh Najafi, Centre for Instructional Technology \& Multimedia, Universiti Sains Malaysia, \\ Penang, Malaysia. Tel: 60-19-412-5197; 98-912-396-2185. E-mail: farzaneh_nag@yahoo.com
}

Received: June 12, 2013 Accepted: July 2, 2014 Online Published: August 20, 2014

doi:10.5539/ass.v10n17p170

URL: http://dx.doi.org/10.5539/ass.v10n17p170

\begin{abstract}
Semiotics is the science of signs. It is known as an approach to expose the fundamental structural elements of the meaning of an object or a term. It comprises of the study of signs, designation, indication, analogy, likeness, symbolism, signification, metaphor, and communication. Semiotic and land art are closely associated with each other. Land art consists of sculptures, carvings, and performances located at specific natural surroundings to deliver messages of love and concern for the environment, even though they are ephemeral or located in inaccessible places they are transmitted by the semioticians. Like all works of art, each piece could be classified as abstract or realistic and would be created using signs and symbols of the artist's semiotic system to code the messages and feelings. The aim of this article is to examine the semiotics of land art based on signs and symbols of landscape through documentary analysis. The findings of the study revealed that semiotics is a powerful tool to reflect feelings and sentiments regarding different landscape. Some implications were also furnished.
\end{abstract}

Keywords: semiotics, signs, symbols, landscape, land art

\section{Introduction}

Semiotics is the science of signs (Eco, 1976, 1979). Foote (1988) regarded Semiotics as a subcategory of the cultural study through which signs and sign systems are investigated as modes of communication; such studies explore the ways of encoding and decoding the meanings of the presented signs and symbols. Furthermore, art and culture are complicatedly interrelated in a way that various features of art works originate from culture; consequently, scripts and signs used by humans in various locations are said to be related to the human culture that makes the role of culture so important in realizing the concept of semiotics in art (Ferreira, 2007; Smith-Shank, 1995; Temple, 2005).

For instance, 'color' can be regarded as ideas or codes which have been expressed for a long time in a society; for instance, in Medieval color symbolism 'black' stands for penance, while white represents innocence and purity and 'red' is a symbol for the Pentecostal fire. Some artists use symbols and signs that have some cultural characteristics to convey their messages to the viewer; fish, snake, hand, foot and goddess are amongst the symbols used in the art land works of Nadalian as an Iranian land artist (Bower, 2010). As an instance in land art of Nadalian (Appendix A), Anahita is an ancient and symbolic goddess of water and fertility in Iranian culture; she is believed to be the one who purified the waters and the milk of nursing mothers. Anahita's image is carved into the many rocks where the flowing waters exist, surrounding her image (Nadalian, 2011).

Another instance would be Nadalian's works whose carvings feature a female figure together with a fish or moon illustrated; female figures represent water goddesses and fertility in ancient cultures and the fish or moon are perceived as the symbols for rain and fertility (Doan, 2009; Ghal'eh, 2009). Nadalian (2011) stated that holiness of water goddess could be perceived at an age of increasing water pollution. Nadalian claimed that art works could be effective when everybody understands the message of the artist; thus, an artist can attain this goal best by using the cultural signs, which are associated with people's life history and beliefs. Like other artworks, land art pieces are also constructed using symbols and codes that must be analyzed and then synthesized for interpretation to discover the intended meanings embedded by the artists.

Semiotics can be defined, based on Smith-Shank (1995) as a wide ranging approach towards the perception of the nature of meaning, the understanding of cognition, culture, behavior, and life. In addition, it also tackles with the perceptions of the people of a given culture, which are the result of that culture and society (Tsotra, Janson, \& Cecez-Kecmanovic, 2004). In the literature, Semiotics is described as the amalgamation of knowledge that has 
resulted from the thematic or systematized analysis and study of the action of signs, called "semiosis', wherever this action of the signs takes place in the world (Deely \& Brown, 2006).

In this path, significant works have been carried out in the early 20th century in Prague and Russia. Due to these developments in this branch of science, it is now well recognized and established in France and Italy. In addition, based on Ivanov (2008) it is making progress and advancements in many countries such as England, and the United States. Beasley and Danesi (2002) maintain that this branch of science is among those issues that have been employed in approximately all aspects of our life amongst which one can name language, art \& advertising.

Following Sebeok (2001), the acknowledgement of the extensive application of signs and symbols in everyday life is a prerequisite for the perception of the concept of "Semiotics". However, as it is expected, since the both philosophically and practices regarding, "Semiotics" seems to be found in all places and since it has been in circulation for a long time and due to its different forms, it is not an uncomplicated issue. Hence, new readings of approximately anything to emerge such as films, TV programmers, works of art, fashion, etc., needs constant learning of this newly born language (Colapietro \& Olshewsky, 1996; Lawes, 2002).

In Saussure's words, semiotics is a branch of science that investigates the signs and symbols' life within a society. It is regarded as a part of social psychology and branch of general psychology. Semiotics is the study of showing what are signs constitutes of and the study of the laws and rules that govern them (Danesi, 2007). Conversely, Danesi (2002) defined semiotics as a discipline that intends to analyze and study of sign-based behavior and hence should not be utilized as a means of doing a critical approach to political and social systems. In this respect, as is discussed by Hardt (2005), it is considered as the science of signs in which philosophy and linguistics would work the basis of semiotic researches.

It also differs from the qualitative researches that have been done in the traditional manners. In the traditional research, which can be said to carry an 'inside-out' approach, the psychological phenomena such as perception, attitudes, and ideas are extracted out of the participants' head by means of interviews and data collecting methods. The method that is employed by semiotics is, however, the reverse. That is an outside-in approach is used. The question that this approach tries to find an answer to is how these cognitive states enter one's head at first and where have these cognitive states have come from? Lawes (2002) believes in the surrounding environment and cultural context of which the respondents belong to as the source of these perceptions.

Symbols are a broadly unique classification of objects that are familiar to a certain group of people with a certain cultural background and associated with specific emotions and feelings. Particularly, in occasion of dissimilar cultures, different schemas can be activated by different symbols that overlap or related to the cultural and linguistic background of the group (Tsotra et al., 2004). Thus, different factors such as gender, age, and the viewers' knowledge of art and culture have important roles to play in understanding land art works from the visual images produced through photography.

\section{Semiotics in Art}

Semiotics in art works is the study of signs and symbols with the purpose of translating an image into words. In semiotic systems, all types of pictures are considered as representative icons for objects such as photos, drawings and paintings. Pictures mostly have a doubled meaning; visual and symbolic, conventional and arbitrary (Ferreira, 2007).

Semiotics is believed to depend on culture and is regarded as the method with which people make communication, either consciously or unconsciously, via cultural features like the visual image (Lawes, 2002). Consequently, "images in different cultures have different meanings", different communities are expected to analyze and deliver messages differently because culturally different groups may respond to and understand differently regarding the existence of an equal stimulus (Muller, 2005). Moreover, cultural manifestations, like values, myths, symbols (rooted in semiotics) and customs have significant effects on perceiving and decoding the art works (Luna, Peracchio, \& Juan, 2002).

\section{Materials for Land Art}

It is interesting to know that some icons are universal and therefore viewers with different knowledge, background and cultures can understand them (Parker, 2010). Spiral shapes, for example, are among frequently used icons that have been used in different types of art works by different cultural artists. Spiral symbols are found in almost all types of artworks, which might be different in terms of material, size, position of artwork or the concept, and idea that the artists aim to follow; spiral broken stone made by Goldsworthy in 1985 and Spiral Jetty by Smithson in 1970 are among the examples of spiral land art works. Besides, different viewers with dissimilar feelings and knowledge can develop different interpretation of an artwork and the visual message 
being conveyed (Ghal'eh, 2009; Parker, 2010). The spiral shape of Spiral Jetty is an ecstatic symbol of life in the world of man-made death and beyond which moves relentlessly, yet it is tightly coiled like a snake about to spring (Nadalian, 2011).

Semiotic of land art works is the main keyword of the discussion developed in the present study. Land art, as a part of contemporary art, does not enjoy a long history, but it certainly is an art whose nature has been respected since old ages. In land art creation, an artist may turn into a part of the work or, sometimes, use his/ her own body to perform art works relating to his/ her inner involvements at nature. Examples of such art works include the art works of Goodarzy, Alamshah, Khas, and Maktabi (Maktabi, 2008).

\section{Photography}

Therefore, land artists have to rely on photography to have their works seen by the public; thus, dissemination of land art is mostly attained through visual documentation of the art (Amizlev, 2001). This can be regarded as a strong reason itself, justifying the importance of studying and examining the role of photographers and photography in the land art, contributing to the development of a new attitude in photography. In other words, this is perceived as an "inter-media" and "reciprocal" art; It is an inter-media because photography is, sometimes, applied as an instrument to explain another artistic type, but it remains dependent on the concept and view of that art which needs photography to be offered (Edwards, 2006; Wall, 1965).

For investigating and understanding photography in environmental art works, it is necessary to discuss the items that are capable of influencing the process of decoding messages of environmental art photography; such items include orientation of photos, angle of photography, shadow, light etc. A photograph is an image that presents a subject, which is the main character in the photograph, in relation to its environment. The subject can be a person, an animal or a thing, or a group of them. The subject's environment is expressed in the form of the foreground and the background. Other objects or things in the foreground and background such as grass, trees, the sky, the cloud, and the horizon can also be incorporated to enhance the presentation of the subject. Thus, the features and the pose of the subject together with the surrounding elements of color and texture and the objects in the foreground and background combine to create the full message of the photograph.

The subjects of the land art photographs are the land artworks but they are located in the environments where they are created. They are at times to be "blended" into the surrounding environment as in Nadalian's artworks and as other instances represent foreign intrusions into the environment as in Alamshah's artwork. They can also be independent of the environment, such as some of Maktabi's works. The features of the artworks do not change but the photographer may employ various photographic elements or camera techniques to present the artworks in photographically better presentations. Thus, a long shot would present the artwork together with its surroundings while the close-up shot would focus on the artwork without its surrounding. Thus, the role of the viewer is to read the signs and symbols of the artworks and to take note of the contribution of environment employed in the artwork.

The focus of this research is on the effects of the size of the image (Close-up and Long shot) as these are two dominant and effective factors of photographic image presentations. It is worth mentioning that the concept of each image or photo of land art works might also be changed with different lights, seasons, and angles. In addition, vertical photographs, emphasizing depth or height, generate a sense of strength. Holding the camera vertically is appropriate for taking pictures of vertical subjects such as tall buildings, tall trees, tall animals, and waterfalls (Hedgecoe, 2006, 2008). On the other hand, horizontal photographs generate a sense of calmness or stillness, emphasizing the width over height for taking some subjects such as a skyline, a ranch-style house, etc. (Hedgecoe, 2004). Every single characteristic of these structures, employed by photographer, to show the ideas that are goal of the project photos, will be coded within the given photo in different angles, orientations or so on (Peterson, 2003).

The selective use of the close-up, medium shot, long shot, and other photographic elements is a visual technique for directing a viewer to a visual message. In film and television, long shots are used for orientation or placement of the subject in an event while medium and close-up shots deliver the action and the story using the factor of interpersonal communication that an intimate distance suggested by close-up shots increases viewer involvement with the subject (McCain \& Driver, 1973). These effects extend to the photograph as reported by Williams (1968) that the static shots were just as effective as the varied camera shots in providing high interest level.

In the description and analyzing or decoding a photo, it could be stated that in a long shot photograph like a photograph taken by a wide-angle lens, everything, including all the mess on the ground could be visible (Long, 2012). A wide-angle lens make may make distortions between the foreground and the background in a particular way and make the foreground exaggeratedly enormous (Hedgecoe, 2004). Using a wide-angle lens, the attention 
of the viewer is drawn to the foreground instead of the subject and introducing the concept of scale (Peterson, 2003 ) in the photograph. On the other hand, using a long shot allows the subject to be emphasized instead of the foreground or the background. In fact, wide-angle lens can be used for hiding a distracting element in the background behind the subject; while, this is not practicable with a telephoto lens (Dijck, 2008). Using a wide aperture and a limited depth of the field further creates a possibility to take a photo with blurred background (Wells, 2004), removing all references to the subject's surrounding.

Thus, for reading an image or achieving the intention of the artist or photographer, attention needs to be paid to several items such as semiotics and photographic effects, some of which are mentioned above as necessarily important. However, one of the most important items that have serious effects on decoding or reading a photo by the viewer is the culture of the viewer and his knowledge of the signs used. Following practices in their culture, people use signs to perceive the symbols they use; the ability to interpret pictures as symbols depends on the set rules or social conventions, which are shared by particular people (Bolin \& Blandy, 2003; Quin, 1997).

The study of media related to art and popular culture, including photography, via visual culture permits interpretation of features and symbols, which have different social connotations. Decoding and reading images and media (text, image, video, audio, etc.), will result in becoming more visually literate. This knowledge will become a skill for using images and texts to develop interpretations and understanding the discourses according to cultural codes (Aiello, 2006). Reading images necessitates cultural knowledge and familiarity of the sign systems of a culture; and their meanings are perceived within the conditions of their production and consumption (Smith-Shank, 2004).

Therefore, the interpretation of an image depends on the viewer's historical and cultural backgrounds (Ownby, 2011) as well as his/her understanding of the photographic elements. Thus, the act of image interpretation from photographs also includes a psychological dimension offered by the elements of photography. It has been shown by architectural studies that photographs are exposed to procedures of interpretation involving the principles of spatial envelope and extension of boundary (Oliva \& Torralba, 2002). A scene's structure is described by the specifications of the space boundaries (e.g., the size of the space, its openness degree, and the perspective) and specifications of its content (Oliva, Park, \& Konkle, 2011). The values that each scene image takes for each spatial envelope property can describe the very image. These values can then be portrayed in descriptive terms; for instance, about a given scene's degree of openness such as "very open/panoramic", "open," "closed," or "very closed/enclosed" (Oliva \& Torralba, 2002).

In this framework, a forest would be characterized at a middle level as "a natural environment which is enclosed and has a thick, isotropic texture" or as a substitute for "a location which has trees, bushes, and leaves". Likewise, a particular street scene image could be defined as an "artificial open-air place with a perspective that is moderately cluttered" (Oliva \& Torralba, 2006). This level of explanation makes sense to viewers who can understand the probable semantic classifications of the scene. Oliva and Torralba (2002) reported that scene images, which people judged to have a similar categorical relationship were closely projected in different dimensions.

Intraub and Richardson (1989) stated that when pictures of scenes were offered to the observers and they had to remember the scenes, they systematically remembered spatial features more than what was actually shown. This phenomenon is called boundary extension. Boundary extension is dynamic to different tasks further than drawing, like evaluation and border alteration to various types of images (Intraub, Gottesman, Willey, \& Zuk, 1996). Its operation takes place over a series of periods from minutes to hours and it is true for young children as well as for older ones, i.e., observers offered a scene will memorize the information specifically about around the edges of the scene (Johnson \& Onwuegbuzie, 2004).

When observers reproduce information of a scene that is not visible anymore, but the viewer memorized it, a systematic distortion of space occurs. When a close-up scene view is offered to an observer, the presence of boundary extension implies that this scene view might be offered at a wider angle than its original presentation angle (Oliva et al., 2011). Consequently, if the second stimulus is presented slightly wider than the original, this should match the representation in scene-selective areas and show a large degree of attenuation. Conversely, if the order of these stimuli is reversed, the representation of the wide-angle view will be very different from that of a subsequently presented close view (Harris \& Jenkin, 2011).

Thus, other than, the historical and cultural contexts, there are two additional paths that the viewer may apply in interpreting images from photographs with the choice driven entirely by the strength of the features or photographic elements of space and composition embedded in the visual literacy (Heath, 1977). For realizing how such works of art attain their cognitive effects, it is important to consider that people may share lots of 
beliefs, practices, and aspirations, but don't recognize that these are commonly held, and they are not able to articulate them (Smith-Shank, 2007). Most often, people are not aware that to what extent other members of society share their values, beliefs, and aspirations. They are not either aware of the extent to which they are members of, and how they participate in, a certain culture (Muller, 2005).

With reference to the in land art, Novitz (1996) mentioned that no efforts are made to foster a cultural identity but the artists wish to provoke the viewers' cultural self-satisfaction and persuade them to re-examine their views of their own cultures. Through several other types of art works like poems, novels, films and plays, all try to establish a common view of a culture in a pretty direct and non-critical manner, by providing various sorts of reasoning for that view (Hjort \& Laver, 1997). Therefore, this study intends to investigate the blunt semiotic interpretation and message understanding of land artworks.

\section{Semiotics and Photography}

Sometime, land art is out of the reach of common people. Generally, it is not found in the museums, however, it can be practiced and observed in outer and natural spaces. Therefore, it is difficult to enjoy the land art and be completely appreciated (Amizlev, 2001; Archer, 2002; Grande, 2004, 2005). Photography plays a vital role in the dissemination of the messages and meanings of the land art due to a combination of interconnected factors. It is used as an exposure to the public about the land art through different means of visual documentations (Nadalian, 2011). However, the photographs can only be substitutes of an illusion of the real art world concerning with viewing practices (Amizlev, 2001; Marasy \& Sedigh, 2009).

Millis (2001) asserted that a photograph is an aid to the memory, but presents only half of the truth. For an artwork, a series of shots of taken at 360 degrees would better help understanding the surroundings, formal aspects and different elevations while different seasons, moments of time, monumentality and the conditions of weather can change the perspective of viewing, but the size of a photograph cannot convey the reality of the subject (Amizlev, 2001). The Photograph is always dependent on the photographer's choice of angles or points of view of his/her subject matter. In addition, the images will have additional photographic elements taken from the sites as well as due to processes of documentation (Alloway, 1970).

Hall (1997) affirmed that an object like a mountain seen from a distance might give different feelings and understanding to someone who enjoys being present there and seeing it from the same distance. The photographs, as an impression of the real object in a moment, may have recorded considerable facts as well as metaphoric and symbolic messages; however, the deficiencies reduce the importance of being real. Photography is meant to be a medium of reporting, not the subject of discussion, but it is not a neutral medium. The interventions through photography come in the form of composition, use of perspective, use of colors, types of shots or size of subjects and types of angles (Millis, 2001). For land art, types of shots, namely, long shot and close-up shots using objective angles are important in accurately documenting the art works, but the use of additional techniques would embellish the art works with unintended features and visual elements.

Despite the intention to be accurate and truthfully report or preserve the semiotic systems formulated by the artists in conveying their messages, the process of recording the images through photography inadvertently adds new elements to the images of land art. According to a study conducted by Amizlev (2001) where the artists were interviewed regarding the representation of their symbols and messages in the photographs of their art works and they reported that they were happy with the photographs and agreed that all of their signs and symbols were clearly captured. However, participants also noted that the photographs of their art works also contained additional embellishments of photographic elements.

According to Tavin's (2000) study, photographs present images that inscribe events or evoke mental and emotional reactions and act on a viewer in three ways, namely, a) in the form of effect/ emotion, i.e. in the way people feel; b) in the form of judgment, i.e. in their view of how people should or should not behave; and c) appreciation, i.e. in how things are assessed or valued. These photographs can also be interpreted using Gestalt principles (Oliva \& Torralba, 2002) or using semiotic principles (Barthes, 1978) or a combination of these. Thus, extracting a land artist's message from a photograph of a land art is not a straightforward process. Together with the artist's work and semiotic system, the photograph is packed with elements that evoke emotions, cognitive challenge involving interpreting, and understanding the signs and symbols, and judgment and appreciation of the effort to change of views towards the environment.

With respect to the use of art in communicating ideas and concepts through the incorporation of signs and symbols, as well as the temporary existence of land art works, it is vital for the land art pieces to be photographed in a manner that will accurately deliver the intended message of the artists to the viewers. Thus, there seems to be a gap between what and how photography can be used to understand land art works and an 
empirical study that can be conducted to ascertain it. Photographs of land art pieces offer a unique blend of artworks with their own semiotic system embedded with the elements of photography. The viewers are now offered two or more simultaneous ways of interpreting the visual presentation, namely, focusing on the semiotics only and ignoring the additional contribution from photography, or focusing on the semiotics elements only, or blending the semiotics and the photographic elements together to enhance the interpretation of the land art pieces.

The embellishments of the photographic elements to the artworks by techniques such as composition, perspective, angle, and size of shots, such as long shot or close-up, may distract the viewers away from the main concept of the artworks as intended by the artists and produce other unintended meanings or reactions. For example, long shots contain more visual elements from photography in the form of foreground and background that may distract the viewers, while close-up shots have less input from photography and enable the viewers to focus on the semiotics of the art works, but at the same time present the works in a view that is detached from the environment that they were intended to protect. Understanding, denotation, connotation, etc. from the photographs would be different when the details in the visuals are changed by the use of these different photographic representations.

Studies involving image sizes or types of shots are few in number. McCain and Driver (1973) reported that image sizes could differentially affect a viewer's attitudes and perceptions in the context of television. They reported that the athletic body type was perceived to be more physically attractive in long shot than in the close-up, and that males were perceived to be more physically attractive in close-up and medium shots but females were perceived to be more dynamic in long shot. However, no study has investigated whether the semiotic interpretations of the land art works are preserved when presented through various photographic presentation modes that unavoidably may exclude some semiotic cues and include visual elements and cues which are not part of the original artwork.

As regards differences in man and woman approaches, Belenky, Clinchy, Goldberger, and Tarule (1986) demonstrated that women and men take different approaches to learning and knowing. Women's approaches are process-oriented, intuitive, and personal as opposed to the approaches of men, which are goal-oriented, rational, and impersonal. Welling (2005) defined intuitive processing as that which involved hunches, gut feelings, first impressions, and the appearance of meaningful visual images, words, memories. The contrasting approaches by gender may have specific effects on outcome, thus, an additional question investigated was: as the images of land art could be interpreted based on the artists' semiotic systems as well as from the photographic properties, do viewers with different gender and levels of art knowledge process the images of a land art works at the photographic level or at the semiotic level.

What is very important in the achievement of the purpose of the present study is without doubt an introduction of the photographic semiotic system of land art works images can be considered as a language. They actually speak to us. This language can directly cause, based on Keddie (2009), the eruption of emotions and feelings, ideas and curiosity; memories and our experiences are brought back to us from them, and they restore and reach that part of the brain that is unavailable to us through words alone. Symbols, which are deeply rooted in different cultures of various societies, can be found all around us. They are scattered everywhere. What is necessary is the ability to know their language. For instance, understanding and reading of a piece of song require the knowledge of their language. This is also true for the reading of images. Capability of reading different images and visual signs, in diverse art works, demand specific knowledge.

\section{Semiotic Theories}

Regarding modern semiotics analysis in the early $20^{\text {th }}$ century, two scholars can be named as the pioneers of this science- the Swiss linguists, Ferdinand de Saussure $(1857$ - 1913) and the American philosopher, Charles Sanders Peirce $(1839$ - 1914). The semiotics, which has been dominantly used for the science of signs, was first introduced by Peirce to call his system. Hence, as maintains by Berger (2011), there have been differences between the terms used by Saussure or semiology, and Peirce or semiotics. Semiotics has been summed up, in the theory of Saussure (1896), as a sign: signifier (an object) and signified (an attributed meaning to the object) (Özbilen \& Kalin, 2001) as shown in Figure 6.1, the first refers to the form which the sign takes, the latter to the concept to which the sign refers to (Tavin, 2000). This concept belongs to the structuralism school of thought, which was founded around the concept of semiotics by him (Crow, 2003).

Saussure basically, viewed sign from a linguistic perspective. Hence, Saussure did not take into consideration the role of the reader since; he was only concerned with words (Chandler, 2007). As noted by Crow (2003) Saussure's structure is internal. Therefore, he did not consider the relationship that exists between the signified 
and reality (Magdy, 2008). Other branches of science have also been influenced by Saussure's theory amongst which one can refer to anthropology, sociology, and literary criticism as the main ones. Basically what structuralism proposes as its central tenet is that, whether language or media, the phenomena of human life can only be intelligible when it is only studied through the consideration of the network of relationships which is present among them by making the sign and the system the primary concepts in which the sign is embedded in (De Saussure \& Baskin, 2011).

Moreover, the signifier and signified in Saussure's linguistics theory are the sound and the thought respectively (Tavin, 2000). The linguistic sign is not conceptual or phonic and it is not either thought or sound. Hence, the sign is regarded as the whole association that links sound and idea or in other words the signifier and the signified (Chandler, 2007). In this theory, the sign enjoys not a concrete but an abstract nature. To put it in Saussure's words "A sign is not a link between a thing and a name, but between a concept and a sound pattern" (De Saussure \& Baskin, 2011).

A sign in Saussure's theory both is a signifier or the sound pattern and a signified or the concept; that is, as it is shown in Figure 6.1 by Chandler (2007), a totally meaningless signifier or an entirely formless signified is impossible. Nonetheless, what Saussurian model today is applied for is not only the giving of a definition for the signifier to deal with the sound pattern, but this model is regularly used to interpret the signifier as the sign material that according to Morgan and Welton (1992), can be seen, heard, touched, smelled or tasted.

What semioticians do is not only the decoding of the meaning through the determination of the relations between the signs and their signified, but they also analyze the relations that are present among the signs in a multifaceted message (Moriarty, 2005). In this regard, Sebeok (2001) contends, "Saussure counts the connection between the signifier and the signified as an arbitrary relation that is willingly established by human beings and/or societies" (p. 6). Therefore, it can be seen that as is mentioned by different scholars, a fixed relationship cannot be proposed for the relationship of the sign and its meaning or, in other words, this relation is a conventional one (Iser, 2006; Sturken, Cartwright, \& Sturken, 2004).
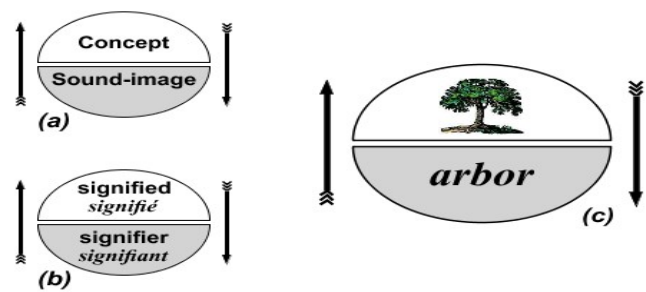

Figure 1. Saussure's schema of the sign

\subsection{Peirce's Theory of Signs}

Peirce (1839-1914), known as "the father of pragmatism" (Fontrodona, 2002), perceived semiotics as a logic theory (Petrilli \& Ponzio, 2007). The view is almost similar to the linguistic worldview theory by Russian academics (Ming, 2012). Peirce asserted that semiotics could be applied as the official dogma of signs in visual, verbal, and mathematical field (Chandler, 2007). The theory was systematically built on the philosophic foundations by scholars and philosophers such as the Stoics, Plato, the Scholastic Realists, Locke, and Kant (Smith-Shank, 1995).

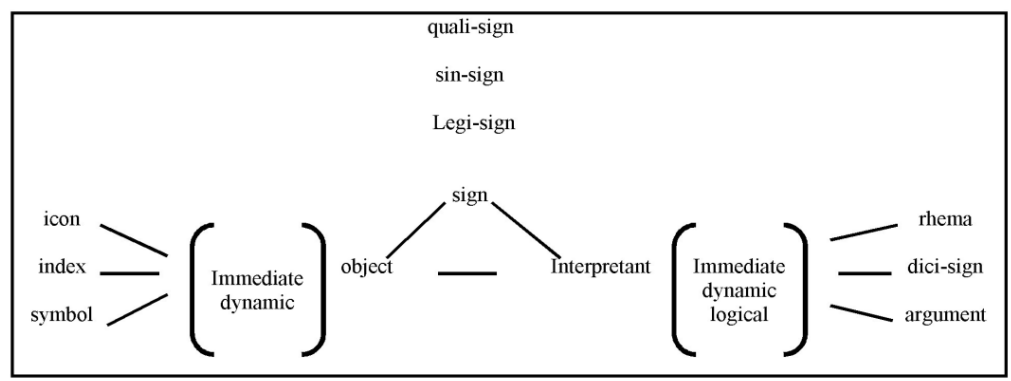

Figure 2. The structure of the sign notion of Charles sander Peirce

Peirce defined signs as something that has a meaning to a person in some ways (Rolling Jr, 2008; Smith-Shank, 1995). The mind will readily form an interpretation when a sign that refers to an object or referent stimulates it. 
Based on Peirce's theory, visual signs used are usually representative of objects that are similar to it (Moriarty, 2005), yet it can also be inspired by the relationship to the object represented (Chung, 2006). Peirce's theory of signs is founded on some conjectures such as icon, index, and symbol. The model of theory is shown in Figure 6.2 elaborated by Ming (2012).

In this term, visual signs are logically connoted to be "similar to" (as an icon when there is a visual resemblance), "contiguous to" (as an index when the relationship to its object is in terms of causation), or "conventionally connected to" (as a symbol that relates to its object through a set of rules) something familiar to the interpreter (Cawson, 2006; Crow, 2003).

\subsection{Theory of Roland Barthes}

Following Peirce, in the 1950s, Barthes (1978) presented the 'semiotic method', after which, the theory of semiotic was utilized widely in critical theory related fields, a division of cultural studies whereby the relationship between audience or viewer, his environment, and the sociology of group behavior is investigated (Danesi, 2002).

An exceptional vision of photo and their visual and implicit messages is brought about by Barthes semiotic theory of 'A Photographic Message'. Once exploring the tangibility of an image, Barthes' theory is of use (Graham, 2012). Figure 6.3 shows the model of Barthes semiotic theory (Özbilen \& Kalin, 2001). The observer comprehend that the text and photo are connected and they give meaning to each other. The fact that shared denotation is not constantly shared is the chief flaw of the Barthes' theory. The artist and viewer are presupposed to have the identical cultural background in The Photographic Message (Barthes, 2000).

A prearranged scheme of signs, particularly images, as communal events are concentrated on by Barthes' (1978) semiotic theory. The manner that these signs become the codes of cultural familiarity and ideologies is highlighted by his theory. One should comprehend the cultural ideologies that are developed by complete realization of the entire hidden messages in a photo. Denotation and connotation, as Barthes' theory has stated, create meanings. The connotation is the meanings implicit or hidden in a sign while denotation is the literal meaning or sign reference (Özbılen \& Kalin, 2001).

Therefore, devoid of a sign or code, a pictorial photo independently seems to be denotative. Nevertheless, Barthes declares that being mythical is very important to the extent that the denotation of an image has every alteration to be so (Barthes, 1978). Due to the feature of an image that symbolizes and expresses cultural, ideological standards, he employs the term mythical. Consequently, where there is a mutual life of denotative and connotative meanings in a photo, there is a pictorial inconsistency (Graham, 2012). The cultural and historical constituents of an image have the same importance of the image as well. To recognize cultural ideologies and meanings inside an image, some forms of connotation are employed (Lockwood, 2007). As a result, the observer's recognition of the historical and cultural information affects the connotation. Therefore, as the information of the people differs, they may have misinterpretations of a photo's message (Magdy, 2008).

The caption of a photo brings even additional meanings, even if the connotative processes intensify different communal meanings. According to Barthes (2000), during the years, images and their cultural messages with or without captions have altered. By inserting six connotative processes, which are employed to develop and fortify the meanings in an image, a photographer is able to insert a message different from the cultural message. These processes are as follows: fake effects (forged images or digital editing), pose (the position and displaying of people), objects (putting objects in the image), photogenia (the image technical facets like exposure, lighting, and printing), aestheticism (simulation of artistic modes), and syntax (placement of images in a string) (Barthes, 1978; Ivanov, 2008).

\begin{tabular}{|l|l|l|l|}
\hline Denotation & Signifier & Signified & \multirow{2}{*}{} \\
\hline Connotation & Sign signifier & Signified \\
\hline
\end{tabular}

Figure 3. Semiotic model of Roland Barthes

\section{Semiotics in Art and Culture}

For Foote (1988), semiotics is viewed as a subcategory of culture. In this perspective, sign and sign system are considered as modes of communication by which the way in which the meaning of sign and symbols are encoded and decoded have been studied. Semiotics provides a tool for the analysis and conceptualization of the 
manner individuals and collectivizes have communications and interactions either in a denotative or connotative way.

Even though the semioticians in the field of art have done much effort to explore different aspects of semiotics in various fields such as Semiotic Advertising and Culture, Semiotics in Marketing, Social and Musical Semiotics, Visual Signs as Semiotics, Film and Photography Semiotic, etc. however, as is mentioned by Ferreira (2007) regarding written sources, the analysis of signs and symbols is a new branch of art. Considering semiotics from an art perspective, it is the study of visual iconography based on the used icons in it. If the viewer aims at the right understanding and appreciation of the visual and the full understanding of the meaning conveyed in it, having knowledge of semiotics and symbols seems necessary. Thus, as also mentioned by Davison (2009), semiotics is the study of icons, indexes and symbols. Dictionary of Literary defines semiotic or semiology as the study of symbol systems or as stated by Masood and Zain (2011) it is the offering of meaning to symbols either in linguistic or non-linguistic form of it. Not only the relationship of symbols and objects is studied in this branch of knowledge, but it also concerns the exploring of the relations between the symbols of the symbol system or code structure (Chandler, 2007).

Hence, since one can easily see visual works in all types of art works such as photography, painting, drawing, and poster, it can be concluded that as is discussed by Masood and Zain (2011), what is conveyed by art is our present life, how people respond to different events, situations and phenomena as well as the artist's feeling and passion. As many scholars such as Ferreira (2007), Temple (2005) and Smith-Shank (1995) have stated for the perception of the concept of semiotics in art one needs to take into account the role of culture. This is due to the fact that not only the two phenomena, that are art and culture, intricately related to each other, but various features of art works are rooted in culture. As a result, one can truly come to this conclusion that the scripts and sings that have been employed by human in different situations have roots from the human culture.

Different scholars have defined culture. For Tavin (2000), it is a fundament, a product, an art and identity, which since it have deeply influenced the everyday lives of its members, the people of that culture are engaged with it and use it in their everyday lives. It is a very complicated and hence diverse entity, which is manifested differently from place to place or from person to person. Concerning the fulfillment of human requirements, the society should predictably accept and respect cultural differences (Shahidi, Bemanian, Almasifar, \& Okhovat, 2010).

As an example, Medieval colour symbolism can be mentioned in which black, white, and red symbolized penance, innocence and purity, and Pentecostal fire respectively. Abstract painters for the expression of ideas in the early 20th century also exploited the use of colour. The first attempts to produce a 'grammar' of for the works of Malevich, Mondrian, Kandinsky and others (Kress \& Van Leeuwen, 2002, 2006) did the language of colour.

Gage (2000) stated that a systematically hermetic prospect of universality was offered by this 'language' and 'grammar'. However, the question has remained unanswered that whether the try to change the semiotics landscape via the development of a language of colour is just a mere failure in the 'first try' (Halliday, 1993) or the end of all of the attempts made is unclear and requires to be studied more (Kress \& Van Leeuwen, 2002).

\section{Visual Semiotics}

It was during the $20^{\text {th }}$ century that semiotics developed to its present status which is known as social semiotics (Chandler, 2007; Van Leeuwen, 2005). It has extended to also cover and apply to social constructs and has developed beyond the structural conventions of the traditional concepts of signifier and signified (Aiello, 2006; Chandler, 2007). In addition to this, many scholars Barthes (1993); Jewitt and Oyama (2001); Van Leeuwen (2001) has pointed out to the inclusion of visual culture in social semiotics.

For rendering photograph within the area of visual semiotics the French semiologist, Barthes, is regarded as the accepted source. To be more exact, two levels of denotation and connotation of photographic functionality were constructed by him (Aiello, 2006; Hall, 1997; Van Leeuwen, 2001). According to Van Leeuwen (2005), the way of representation is what the Barthesian visual semiotics deals with. To put in other words, it is the analysis of what and how a photograph represents. The minimally functioning of the image at two levels is the answer of Barthes to the question representation. This is what is explained as "layering of meaning" (Van Leeuwen, 2005). In this regard the first layer deals with who or what that is depicted or in other words the denotation layer, while the second layer or the connotation layer explores the ideas and values that are expressed via what is represented or in what way it is represented. 
According to Rose (2011), regarding from an epistemological perspective, the likeliness of the signifier to the signified is the first instance of the visual image that is functioned iconically. However, this is not the case for the second instance of the photographic image. At this level, a deep ontological shift can be seen and meanings are conveyed more symbolically at the ideological level. Therefore, one can explore the different forms of stereotyping or representation such as racial, gender, etc. at the connotation layer within images of visual mass media (Murray, 2008; Ownby, 2011; Wells, 2004).

\section{Land Art}

In line with the descriptions and outlooks offered, it could be mentioned that the Land art or all arts in the nature is the creation of a conversation, which is going on between the artist and nature (Mikash, 2009). The environmental artist tries to escape from the dark, noisy, and small environments of the galleries. He is interested in seeking refuge and protection to the earth and nature and to be able to make a link and a dialogue with it (Lucie-Smith, 2002). Land Art engages creating sculptures by means of merely natural substances collected close to where the sculpture is built. A lot of them are transient and will live merely a short time earlier than the tide or the wind destroys it. The photographer should try to take the most essential and lively instant of all sculptures in an image before their destruction (Grande, 2004).

According to Kastner (2010), Land artworks can take people to a trip; they are appealing to one's feelings as well and incite one's cognition. They create the mood of going through a novel aspect and stepping another world, time, position or mode of believing (Lailach, 2007). When considering landscape architecture or land-art, the aforementioned issues can be extremely seen, since these artworks will not enter any museums, they ought to be independently observed and felt on their original position, not in a gallery in which many artworks can be concentrated and focused on in one session (Jansa, 2011).

According to Miles (1997), another specific matter is the prevalent clarification of these artworks, they are not seen just by specific art-concerned people; they are observed by a large variety of people, who perhaps have not faced with art in museums and galleries. Land-Art as an interconnected artistic mode is somewhat incomprehensible, since the word covers a huge variety of works and artists. Many modes have a merely peripheral association with others (Mikash, 2009). Dempsey (2010) believes that Land Art is also named as "Ecological Art", "Earth Art", "Earth works", "Environmental Art" and so on. In the middle of the 60s, the earth started to be a replacement for picture as an artistic mode that the tendency to go by the limitations of conventional art performance, like painting and sculpture, primarily in the facet of substances and working sites (Jansa, 2011; Lailach, 2007).

In addition, Weilacher (1999) stated that land art is attempting to recreate a probable association between human and nature in a nonviolent place. According to him, land-art is actually grasped by looking for a novel language in the nature; however, it has gained such a fashionable appearance that its real notion is not much talked about. He thinks, nowadays, any kind of apparently the artistic plan is regarded as land art, devoid of critical outlook and exclusive of a great deal of admiration about its real message.

According to Lailach (2007), artists in the US and Europe went out of cities and created a novel kind of artworks, named land art. They designed works for places exterior the thin halls of galleries and museums. They started with departing from fleeting improvements or hints in landscapes, in the deserts of America, or in the Scottish deserts. Land art in its early phases was extremely influenced by increasing care for environmental matters and risks of environmental pollutions and the dangers that may be caused by consumerism in the modern world in the future; many artworks express dissimilarly noticeable meanings about the particular subjects (Stieff, 2011). Considering this subject, Earth artists make us view the art in landscape, or care about the nature and give value to it as much as we give to art (Dempsey, 2010).

Tufnell (2006) stated that Land artists made a significant worldwide movement, comprising constituents of plainness, performance, photography, sculpture, and abstract art. Similarly, novel modes and facets of dealing with earth are illustrated by the artists who have also no fear of mixing these approaches with notions of design and art. Land art can reinstate landscape architecture and its aged agreement for the captured connection of places and visions (Grande, 2004; Jansa, 2011). John Dixon Hunt thinks that land art is exceeding for its original sentiments and its fair source of visions in the gloomy conceptual view of landscape architecture (Weilacher, 1999).

The major argument of the Soros (2012) study, in the distorting the limitations between land art and poetry in the work of Zurita, is about two works that are entirely opposite each other in their configuration and transience; however, both could be realized as land art or earthworks in modern art history expressions (White, 2012). One is a temporary airborne artwork that was done in 1982 in the sky over New York City as Chile was ruled by a 
military authoritarianism. Actually, it was the verse "La vida nueva". It includes fifteen lines written in the sky using airplanes that ejected smoke with flying in a dot-matrix style. Photographers took pictures from this artwork (in five parts in sets of three) like other earth art or ecological artworks, performances and so forth while this artwork was being made by airplane in the sky. However, it was a particular artwork since it was done not on the earth but in the sky. Chilean artist Downey also recorded it on video in 1982. The second artwork was a poem, which was written, on the desert in 1993. It was done in northern Chile's Atacama Desert once democracy had come again to the country that was everlasting and earthly. This written artwork was taken picture in black and white and added in the book La vida nueva in 1994.

In this study after discussing cited art works, Soros (2012) clarified the concept of this artwork. He stated that a practical notion for comprehending this type of work is the concept of icon, text, which was created by Talens (2009) in the Spanish critical medium. Based on Zurita's works, the textual discipline comprises of a visual text, which is also a printed text. In this regard, textual and iconic principles exist at the same time. Prior to discussing the land art, which is connected with Zurita's works, it is significant to talk about modern art works that employ this process in an attempt to place them in a visual arts' framework. In the conclusion, the researcher, following a number of assessments, placed Zurita's works in a visual art framework, similar to land art, both due to their literary principles and their multifaceted, iconotextual mode of presentation (Soros, 2012).

\section{Review of Literature Pertinent to Land Art}

Thornes (2008) declared that Environmental art is offered as a novel type to explain works of art that are openly representative of the environment and also works of art that are evidently not related to the environment. It is clear that this new type of art, nonrepresentational performative environmental art, should be explained as there were many labels given to this sort of art since the late 1960s.

Amizlev (2001) explored the association between prehistory and environmental art or land art as an art form. While comparing the works of some art critics, he realized that some land works are similar to those of the Nazca lines in Peru; megalithic remained approximately the same throughout Europe, Japan, the Middle East, and Africa; and the Hopewell and Adena mountains were found to be the same in the Mid-eastern United States, whereas others were organized astronomically.

Contrary to Amizlev (2001) who examined the link between land art and prehistoric art works in the nature, Deldadeh (2009) centered on ecological art and environmental tendency in Iran. She declared, in Iran, propensities to ecological subjects were not primarily and critically centered by environmental artist as a concern in their artwork; however, in current years, particularly in Iran, environmental matters and crises develop a striking concern in shaping the works of art. This very fact influenced many governmental and personal organizations to be more cautious about environmental matters and join the artists of this artistic movement to encourage the community accepting this global problem and discover novel answers.

Heyd (2002) explored the problems recognized in the concept of nature renewal. He continues to analyze Japanese gardens and earthworks, and both kinds of art shapes foreground the connection of art effectuality with nature. He concluded that the counterintuitive way by which these arts connect us with nature could assist us to perceive the way through which it becomes possible to restore nature.

The specified subject relating to land art and the role of photography to the presentation of this art, in this research, demonstrates that a focus of accomplished researches lies in the history of land art, introducing artists and competent projects done in this branch of the arts, and environmental issues.

\section{Discussion and Conclusion}

Semiotics is the medium for translating a picture from an image into words. Not all semiotic elements are universally interpreted in a similar way; some are differently perceived regarding to different cultures. This is a fact that the way that different people perceive things cannot be controlled; naturally because, artworks are not an exception and some people interpret them differently from the artist's intended way. Hence, there are some shared symbols and some very specific cultural messages (Bower, 2010). The documentary analysis revealed that semiotics in art works is the study of artworks' signs and symbols, both individually and grouped into systems of signs that can give the viewer more awareness of the artwork's source and its concept. It is a great source to reflect human sentiments. With reference to the incorporation of signs and symbols in order to use art in communicating ideas and concepts as well as the temporary existence of land art works, it is vital for the land art pieces to be photographed in a manner that will accurately deliver the intended message of the artists to the viewers. The semioticians, in line with the significance of semiology, are suggested to utilize the semiotic theories in order to produce unique and everlasting masterpieces in the area of semiotic land art to reflect the 
feelings and sentiment of higher order. Furthermore, semiotic should be used through a variety of signs as a teaching strategy to produce a classroom resource in order to improve teaching and learning.

\section{References}

Aiello, G. (2006). Theoretical advances in critical visual analysis: Perception, ideology, mythologies, and social semiotics. Visual Literacy, 26(2), 89-102.

Alloway, L. (1970). Artists and Photographs. New York: Multiples.

Amizlev, I. (2001). Land art: Layers of memory, The use of prehistoric refrences in land art (Doctoral dissertation). Montreal, Canada.

Archer, M. (2002). Art Since 1960 (2nd ed.). New York: Thames \& Hudson.

Barthes, R. (1978). Image-Music-Text (S. Heath, Trans. Reprint ed.). New York: Hill and Wang.

Barthes, R. (1993). Mythologies (A. Lavers, Trans. reprint ed.). Random House.

Barthes, R. (2000). The photographic message. Theorizing communication: Readings across traditions, 23(8), 191-199.

Belenky, M. F., Clinchy, B. M., Goldberger, N. R., \& Tarule, J. M. (1986). Women's ways of knowing: The development of self, voice, and mind. NewYork: Basic Books.

Berger, A. A. (2011). Media analysis techniques (4th ed.). London: Sage Publications, Inc.

Bolin, P. E., \& Blandy, D. (2003). Beyond visual culture: Seven statements of support for material culture studies in art education. Studies in Art Education, 44(3), 246-263.

Bower, S. (2010). Environmental artist Ahmad Nadalian.

Cawson, A. (2006). Beyond the digital divide: Harnessing the Internet for cross-cultural dialogue. Zeitschrift für internationale Bildungsforschung und Entwicklungspädagogik, 29(3).

Chandler, D. (2007). Semiotics: The basics. London: Routledge.

Chung, M. H. (2006). Learning with multiple signs: A semiotic analysis of teacher sketch journals. ProQuest.

Colapietro, V. M., \& Olshewsky, T. M. (1996). Peirce's doctrine of signs: Theory, applications, and connections (Vol. 123). New York: Walter de Gruyter. http://dx.doi.org/10.1515/9783110873450

Crow, D. (2003). Visible Signs: An Introduction to Semiotic (3nd ed.). United Kingdom: AVA Publishing.

Danesi, M. (2002). Understanding media semiotics (illustrated ed.). USA: Bloomsbury.

Danesi, M. (2007). The Quest for Meaning: A Guide to Semiotic Theory and Practice. University of Toronto.

Davison, J. (2009). Icon, iconography, iconology: Visual branding, banking and the case of the bowler hat. Accounting, Auditing \& Accountability Journal, 22(6), 883-906.

De Saussure, F., \& Baskin, W. (2011). Course in general linguistics (W. Baskin, Trans. P. Meisel, Saussy, H., Eds.). New York City: Columbia University Press.

Deely, J., \& Brown, K. (2006). History of Semiotics. Encyclopedia of Language \& Linguistics, 7(1989), 216-29.

Deldadeh, Z. (2009). Environmental art and Ecological Tendency in Iran. Unpublished master's thesis, Shahed University, Tehran, Iran.

Dempsey, A. (2010). Destination art. California: University of California Press.

Dijck, J. V. (2008). Digital photography: Communication, identity, memory. Visual Communication, 7(1), 57-76. http://dx.doi.org/10.1177/1470357207084865

Doan, A. (2009). Ahmad Nadalian Iranian Environmental Artist. Retrieved December 3, 2012, from http://www.Abigaildoan.blogspot.com/

Duncum, P. (2004). Visual culture isn't just visual: Multiliteracy, multimodality and meaning. National art education association, 45(3), 252-264.

Eco, U. (1976). A theory of semiotics. Advances in Semiotics. Bloomington \& London: Indiana University Press.

Eco, U. (1979). A theory of semiotics (Vol. 217). Indiana: Indiana University Press.

Edwards, S. (2006). Photography: A very short introduction (Vol. 151). USA: Oxford University Press.

Ferreira, A. (2007). How useful is semiotics as a method for analysing works of art? Retrieved January 25, 2012, 
from http://www.artandperception.com/

Fontrodona, J. (2002). Pragmatism and management inquiry: insights from the thought of Charles S. Peirce. Westport: Quorum Books.

Foote, K. E. (1988). Object as memory: The material foundations of human semiosis. Semiotica, 69(3-4), 243-268. http://dx.doi.org/10.1515/semi.1988.69.3-4.243

Gage, J. (2000). Color and meaning: Art, science, and symbolism. USA: University of California Press.

Ghal'eh, R. (2009). The role of archetypes and mythology in land art. Unpublished master's thesis, Visual art Paradise of Tehran university, Tehran, Iran.

Gifford, R., Hine, D. W., Muller-Clemm, W., Reynolds, D. J., \& Shaw, K. T. (2000). Decoding Modern Architecture A Lens Model Approach for Understanding the Aesthetic Differences of Architects and Laypersons. Environment and Behavior, 32(2), 163-187. http://dx.doi.org/10.1177/00139160021972487

Graham, A. (2012). Roland Barthes. UK: Routledge.

Grande, J. K. (2004). Art nature dialogues: Interviews with environmental artists. State Univ. of N. Y. press.

Grande, J. K. (2005). Artful Ecologies. Nature and environmental conference. University Falmouth Collegeart.

Hall, S. (1997). Representation: Cultural Representations and Signifying Practices. London: Sage.

Halliday, M. A. K. (1993). Language in a changing world. Centre for Language Learning and Teaching, University of Southern Queensland, Toowoomba: Applied Linguistics Association of Australia.

Hardt, M. (2005). Aesthetics,semiotics \& design Strategy plan KHiB (pp. 1-35). National Academy of the Arts.

Harris, L. R., \& Jenkin, M. R. M. (2011). Vision in 3D environments. New York: Cambridge University Press.

Heath, S. (1977). The Rhetoric of the Image: In Image, Music, Text, trans (reprint ed.). New York: Hill \& Wang.

Hedgecoe, J. (2004). Complete Guide to Photography. London: Collins \& Brown.

Hedgecoe, J. (2006). John Hedgecoe's Photography Basics. New York: Sterling.

Hedgecoe, J. (2008). The Art of Digital Photography. England: Dorling Kindersley.

Heyd, T. (2002). Nature restoration without dissimulation: Learning from Japanese gardens and earthworks. Essays in philosophy, 3(1), 12.

Hjort, M., \& Laver, S. (1997). Emotion and the Arts. New York: Oxford University Press.

Intraub, H., Gottesman, C. V., Willey, E. V., \& Zuk, I. J. (1996). Boundary extension for briefly glimpsed photographs: Do common perceptual processes result in unexpected memory distortions? Journal of Memory and Language, 35(2), 118-134. http://dx.doi.org/10.1006/jmla.1996.0007

Intraub, H., Richardson, M. (1989). Wide-angle memories of close-up scenes. Journal of Experimental Psycholo -gy: Learning, Memory, and Cognition, 15(2), 179-191. http://dx.doi.org/10.1037/0278-7393.15.2. 179

Iser, W. (2006). How to do theory. London: Wiley.

Ivanov, V. V. (2008). Semiotics of the 20th century. Sign Systems Studies, (1), 185-244.

Jansa, N. (2011). Landscape artists-Between land, art and landscape architecture. Unpublished master's thesis, Swedish University of Agricultural Sciences, Alnarp, Sweden.

Jewitt, C., \& Oyama, R. (2001). The handbook of visual analysis (Illustrated ed.). London: SAGE.

Johnson, R. B., \& Onwuegbuzie, A. J. (2004). Mixed methods research: A research paradigm whose time has come. Educational researcher, 33(7), 14-26. http://dx.doi.org/10.3102/0013189X033007014

Kastner, J. (2010). Land and Environmental art. UK: Phaidon Press.

Keddie, J. (2009). Resource books for teachers: Imags. USA: Oxford University.

Kress, G., \& Van Leeuwen, T. (2002). Colour as a semiotic mode: Notes for a grammar of colour. Visual Communication, 1(3), 343-368. http://dx.doi.org/10.1177/147035720200100306

Kress, G., \& Van Leeuwen, T. (2006). Reading images: The grammar of visual design (2nd ed.).

Lailach, M. (2007). Land Art Germany: Taschen.

Lawes, R. (2002). Demystifying semiotics: Some key questions answered. International Journal of Market Research, 44(3), 251-264. 
Lockwood, N. (2007). Barthes semiotic theory and september 11th, 2001. Human communication theory, 1-9. Retrieved from http://www.colorado.edu/

Long, B. (2012). Complete Digital Photography (7nd ed.). Boston: Course Technology.

Lucie-Smith, E. (2002). Art tomorrow. USA: Finest.

Luna, D, Peracchio, L. A., \& Juan, M. D. (2002). Cross-cultural and cognitive aspects of website navigation. Marketing Journal, 30(4), 397-410.

Magdy, M. (2008). A Semiotic phenomenology of visual rhetoric: Communication and perception of attributes of cultural sustainability in the visual environment of public housing. North Carolina State University, China.

Maktabi, M. (2008). A view to the contemporary art's approaches; between staing and leaving. Ayineh-y Khiyal $11(5), 30-35$.

Malekinezhad, F. (2012). Application of lens model in measuring responses of urban sculpture between designers and non-designers. Unpublishe master's thesis, Universiti Teknologi Malaysia, Malaysia.

Marasy, M., \& Sedigh, O. A. (2009). A Survey on Operation of Photography in Iranian New Arts. Negareh, 8-9(5), 83-95.

Masood, M., \& Zain, Z. (2011). Appreciating, interpreting and understanding posters via levels of visual literacy. World Academy of Science, Engineering and Technology, 59, 1799-1803.

McCain, T. A., \& Divers, L. (1973). The effect of body type and camera shot on interpersonal attraction and source credibility. Speech communication Assosiation. New York: State University.

Mikash, L. (2009). Nature, culture, spirituality: Land Art as an embodiment of sacred space. Unpublished doctoral dissertation, Colorado, Boulder.

Miles, M. (1997). Art, space and the city: Public art and urban futures. London: Routledge.

Millis, K. (2001). Making meaning brings pleasure: The influence of titles on aesthetic experiences. Emotion, 1(3), 320. http://dx.doi.org/10.1037/1528-3542.1.3.320

Ming, Z. X. X. (2012). The Study of Pierce's Semiotics and the Linguistic World View Theory. SignsInternational Journal of Semiotics, 32, 56-68.

Morgan, J., \& Welton, P. (1992). See what I mean: An introduction to visual communication. Edward Arnold.

Moriarty, S. (2005). Visual semiotics theory. Handbook of visual communication: Theory, methods, and media, 8 , 227-241.

Muller, A. (2005). A concepts of culture: Art, politics, and society. Calgary: University of Calgary Press.

Murray, S. (2008). Digital images, photo-sharing, and our shifting notions of everyday aesthetics. Visual Culture, 7(2), 147-163. http://dx.doi.org/10.1177/1470412908091935

Nadalian, A. (2011). The manifestation of primitive and ancient patterns[ motifs] in land art. Negareh: Shahed University, 4(13), 93-105.

Novitz, D. (1996). Disputes about art. The Journal of aesthetics and art criticism, 54(2), 153-163. http://dx.doi.org/10.2307/431087

Oliva, A., Park, S., \& Konkle, T. (2011). Representing, perceiving and remembering the shape of visual space. New York: Cambridge University Press.

Oliva, A., \& Torralba, A. (2002). Scene-centered description from spatial envelope properties. Paper presented at the Biologically motivated computer vision Germany. http://dx.doi.org/10.1007/3-540-36181-2_26

Oliva, A., \& Torralba, A. (2006). Building the gist of a scene: The role of global image features in recognition. In Visual Perception, Progress in brain research, 155, 23-36.

Ownby, T. D. (2011). Wunderkammers, photographs, and growing up southern: A visual semiotic analysis of self-identitty through autoethnography. Unpublished doctoral dissertation, Colorado State, Fort Collins.

Özbilen, A., \& Kalin, A. (2001). The semantic value of plants in the perception of space. Building and Environment, 36(2), 257-279. http://dx.doi.org/10.1016/S0360-1323(99)00058-X

Parker, B. D. (2010). Assessing interpretability of visual symbols of varied colors across demographic profiles. Unpublished doctoral dissertation, Rochester Institute of Technology, Retrieved, New York.

Peterson, B. (2003). Learning to see creatively: Design, color and composition in photography. Amphoto Books. 
Petrilli, S., \& Ponzio, A. (2007). Semiotics today. From global semiotics to semioethics, a dialogic response. Signs, 1, 29-127.

Quin, R. (1997). In the picture: Reading visual language. Australia: Curriculum Press.

Rolling Jr, J. H. (2008). Rethinking relevance in art education: Paradigm shifts and policy problematics in the wake of the information age. International Journal of Education \& the Arts, 9, 1-19.

Rose, G. (2011). Visual methodologies: An introduction to researching with visual materials (3rd ed.). SAGE.

Sebeok, T. A. (2001). Signs: An introduction to semiotics. Toronto: University of Toronto Press.

Shahidi, M., Bemanian, M. R., Almasifar, N., \& Okhovat, H. (2010). A Study on Cultural and Environmental Basics at Formal Elements of Persian Gardens (before \& after Islam). Asian Culture and History, 2(2), 133-152. http://dx.doi.org/10.5539/ach.v2n2p133

Smith-Shank, D. L. (1995). Semiotic pedagogy and art education. Studies in Art Education, 18(32), $233-241$.

Smith-Shank, D. L. (2004). Semiotics And Visual Culture: Sights, Signs, And Significance. USA: National Art Education Association.

Smith-Shank, D. L. (2007). Reflections on semiotics, visual culture, and pedagogy. Semiotica, 2007(164), 223-234. http://dx.doi.org/10.1515/SEM.2007.027

Soros, J. (2012). Blurring the boundaries between land art and poetry in the work of Raul Zurita. Review: Literature and Arts of the Americas, 45(2), 227-235. http://dx.doi.org/10.1080/08905762.2012.719779

Stieff, B. (2011). Earth, Sea, Sun, And Sky: Art in Nature New York Perstel.

Sturken, M., Cartwright, L., \& Sturken, M. (2004). Practices of looking: An introduction to visual culture. United Kingdom: Oxford University Press.

Talens, J. (2009). Interview conducted by Juan Soros. Pata de Gallo.

Tavin, K. (2000). Introduction: The impact of visual culture on art education. Journal of Multicultural and Cross Cultural Research in Art Education, 18, 20-23.

Temple, T. L. (2005). Influences of visual culture in the design of web-based art education instruction: Using content analysis for interactive research and student opinions to (RE) consider interactive design. Unpublished doctoral dissertation, The Ohio State University, Ohio.

Thornes, J. E. (2008). A rough guide to environmental art. Annual Review of Environment and Resources, 33, 391-411. http://dx.doi.org/10.1146/annurev.environ.31.042605.134920

Tsotra, D., Janson, M., \& Cecez-Kecmanovic, D. (2004). Marketing on the Internet: A semiotic analysis. Paper presented at the Proceedings of the tenth Americas Conference on Information Systems, New York.

Tufnell, B. (2006). Land art. University of California: Tate.

Umbanhowar, E. (2005). Public art: Linking form, function and meaning. Landscape architecture, 98(4).

Van Leeuwen, T. (2001). Semiotics and iconography The Handbook of Visual Analysis (pp. 92-118). SAGE.

Van Leeuwen, T. (2005). Introducing social semiotics: An introductory textbook (illustrated ed.). Routledge.

Wall, J. (1965). Marks of indifference: Aspects of photography in, or as, conceptual art. Reconsidering the Object of Art, 1975(253), 32-44.

Weilacher, U. (1999). Between landscape architecture and land art. Berlin: Birkhäuser.

Welling, H. (2005). The intuitive process: the case of psychotherapy. Journal of Psychotherapy Integration, 15(1), 19-47. http://dx.doi.org/10.1037/1053-0479.15.1.19

Wells, L. (2004). Photography: A Critical Introduction (L. Wells Ed. 3rd ed.). London: Routledge.

White, S. F. (2012). Like a River: An Introduction to Contemporary Latin American Eco-Literature. Review: Literature and Arts of the Americas, 45(85), 151-156. http://dx.doi.org/10.1080/08905762.2012.719765

Williams, R. C. (1968). The value of varying film shot on interest level. Speech Monographs, 35, 166-169.

\section{Copyrights}

Copyright for this article is retained by the author(s), with first publication rights granted to the journal.

This is an open-access article distributed under the terms and conditions of the Creative Commons Attribution license (http://creativecommons.org/licenses/by/3.0/). 